\title{
Have MERcl
}

1 small group of doctors and medical students at Dalhousie University in Halifax, Nova Scotia, is taking the motto "waste not, want not" to heart and 14 training centres around the developing world are getting the benefits of that in the form of expired medical equipment.

It's the product of a program called the Medical Equipment Recovery Initiative, or MERcI, which provides endoscopic disposables, catheters, bandages, gloves, wound dressings and more to developing countries.

The program was the brainchild of Dr. Des Leddin, a professor of medicine at Dalhousie, after he became director of training with the World Gastroenterology Organisation about three years ago. While visiting training sites for graduates in developing programs since assuming the position three years ago, Leddin says he discovered that most of the facilities lacked equipment. "When you come back home, we, of course, have everything. The amount of wastage is striking."

With the help of Dalhousie colleagues and medical students, Leddin created the MERcI program to divert some of that largesse to developing countries.

Two types of equipment are generally collected from Halifax hospitals. The first is materials such as wires required for endoscopic retrograde cholangiopancreatography, which are typically used once and then discarded. Each wire costs $\$ 1000$, or about three times the annual incomes of residents of some countries, notes Leddin.

The second type of equipment collected is that which had expiry dates for use in Canada, such as endoscopic ligation bands and sphinctertomes use in gallstone surgery. "Hospitals have to keep stock in excess of immediate needs. They have to overstock. All of this equipment has an expiry date, but

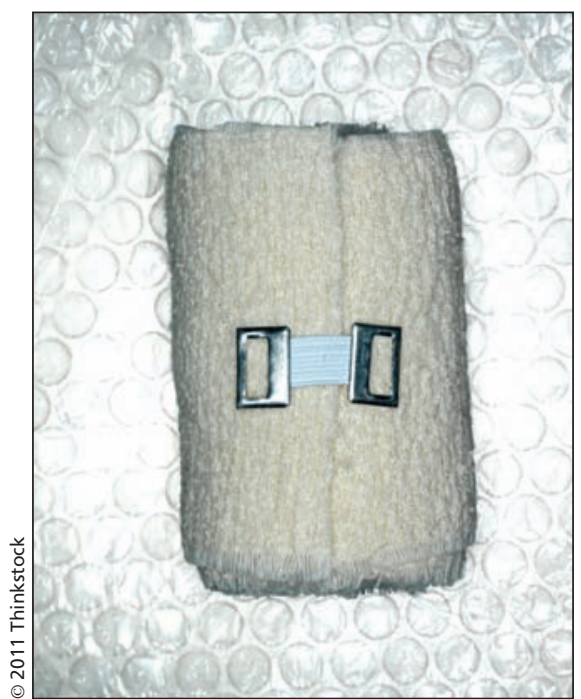

The World Health Organization has guidelines for donations of gauze, wound dressing and other health care equipment to developing countries.

a day or two post-expiry date is really no different than it was 30 days ago," says Leddin.

That does raise ethical issues, Leddin concedes. "We've struggled with this. If this equipment isn't good enough for Canadians, why should we send it to someone else?"

The MERcI team essentially skirts the dilemma with a bit of 'don't ask, don't tell' rationalization. "We don't tell people what to do with this. We ship it for educational purposes - we don't ask how it is actually used," says Leddin. "This equipment is nominally expired. In reality, there is nothing wrong with it. I would use it on myself."

Leddin says the initiative is the first of its kind in Canada, but one that has since been copied by students at the University of Alberta in Edmonton, McMaster University in Hamilton, Ontario, and the University of Western Ontario in London. The one-year-old Alberta program, also called MERcI, has shipped about 400 pounds of supplies, primarily to Uganda, while Operation Green, operated by students at Western, recently made its first shipment to International HOPE Canada, of supplies valued at about $\$ 15000$ and collectively weighing 520 pounds. "McMaster's embryonic program is just getting off the ground," Leddin says.

The inspiration for all those projects was likely the Recovered Medical Equipment for the Developing World (REMEDY) initiative established at Yale University in New Haven, Connecticut in 1991.

Although only "a drop in the bucket," the MERcI project is having an impact, Leddin says. "It's been very successful. We're in the hundreds of thousands of dollars of equipment donated so far."

Leddin adds that the program has now expanded to accept donations of older hospital equipment that is being replaced by newer models, such as endoscopes. "They're perfectly good and at $\$ 40000$ a kick, they're expensive."

MERcI's tendrils may also sprout new initiatives elsewhere - at least that is Leddin's dream. "My wish is that as medical students move through, they will take the program with them.

"I hope that what also spreads is the realization that Canada is an incredibly privileged place," says Leddin.

The World Health Organization has guidelines for health care equipment donations to developing countries (www .who.int/medical_devices/publications/en /Donation_Guidelines.pdf). Among the principles that it asks donors to abide by is that "there should be no double standard in quality. If the quality of an item is unacceptable in the donor country, it is also unacceptable as a donation." donalee Moulton, Halifax, NS

CMAJ 2011. DOI:10.1503/cmaj.109-3832 